OPEN ACCESS

International Journal of

Environmental Research and

Public Health

ISSN 1660-4601

www.mdpi.com/journal/ijerph

Article

\title{
Mosquito Surveillance for Prevention and Control of Emerging Mosquito-Borne Diseases in Portugal - 2008-2014
}

\author{
Hugo C. Osório *, Líbia Zé-Zé, Fátima Amaro and Maria J. Alves \\ Centre for Vectors and Infectious Diseases Research, National Institute of Health Dr. Ricardo Jorge, \\ Av. da Liberdade 5, 2965-575 Águas de Moura, Portugal; E-Mails: libia.zeze@insa.min-saude.pt (L.Z.Z.); \\ fatima.amaro@insa.min-saude.pt (F.A.); m.joao.alves@insa.min-saude.pt (M.J.A.)
}

* Author to whom correspondence should be addressed; E-Mail: hugo.osorio@insa.min-saude.pt; Tel.: +351-265-938-293; Fax: +351-265-912-155.

External Editor: Paul B. Tchounwou

Received: 28 August 2014; in revised form: 28 October 2014 / Accepted: 29 October 2014 /

Published: 12 November 2014

\begin{abstract}
Mosquito surveillance in Europe is essential for early detection of invasive species with public health importance and prevention and control of emerging pathogens. In Portugal, a vector surveillance national program-REVIVE (REde de VIgilância de VEctores) - has been operating since 2008 under the custody of Portuguese Ministry of Health. The REVIVE is responsible for the nationwide surveillance of hematophagous arthropods. Surveillance for West Nile virus (WNV) and other flaviviruses in adult mosquitoes is continuously performed. Adult mosquitoes-collected mainly with Centre for Disease Control light traps baited with $\mathrm{CO}_{2}$ - and larvae were systematically collected from a wide range of habitats in 20 subregions (NUTS III). Around 500,000 mosquitoes were trapped in more than 3,000 trap nights and 3,500 positive larvae surveys, in which 24 species were recorded. The viral activity detected in mosquito populations in these years has been limited to insect specific flaviviruses (ISFs) non-pathogenic to humans. Rather than emergency response, REVIVE allows timely detection of changes in abundance and species diversity providing valuable knowledge to health authorities, which may take control measures of vector populations reducing its impact on public health. This work aims to present the REVIVE operation and to expose data regarding mosquito species composition and detected ISFs.
\end{abstract}


Keywords: surveillance; mosquito; vector; invasive species; flaviviruses; REVIVE; Portugal

\section{Introduction}

Rather than relying on an emergency response, mosquito surveillance allows timely detection of changes in abundance and species diversity providing valuable knowledge to health authorities, which may take control measures of vector populations reducing their impact on health. Never as today has the European region been faced with such concern regarding the introduction and dispersion of Aedes albopictus and Ae. aegypti among other invasive mosquitoes [1,2]. Reports of autochthonous transmission of Chikungunya and Dengue viruses in Italy, France and Croatia [3-6] and the 2012 Dengue outbreak in Madeira Island [7,8] make obvious the susceptibility to these diseases in areas where the primary mosquito vectors, Ae. aegypti or Ae. albopictus are present. Moreover, some mosquito species are causing concern, both in posing a risk to public health and causing massive nuisance problems in some areas due to superabundance phenomena $[9,10]$. The re-emergence of pathogens through native mosquito populations such as West Nile virus (WNV) and malaria has been a major issue in several European regions [11-16]. In this context, the need to enhance knowledge about vector species, their distribution, abundance, and role as vectors of disease agents in Portugal, urged the establishment of a national vector surveillance programme-REVIVE (REde de VIgilância de VEctores)—in 2008 under the custody of Portuguese Ministry of Health. The REVIVE plan included first the General Directorate of Health (DGS), the five Regional Health Administrations (ARS)—namely Algarve, Alentejo, Lisboa e vale do Tejo, Center and North—and the National Institute of Health Dr. Ricardo Jorge. In 2010, the Institute of Health Administration and Social Services of Madeira Island (IA Saúde) joined REVIVE and started surveillance within the program in seven counties. In 2011, a second protocol was signed between the same partakers, and tick surveillance was also included in the national vector surveillance programme. The main guidelines of REVIVE are (1) surveillance of hematophagous arthropods; (2) seasonal and geographical distribution and abundance of native vector species and early detection of invasive species; (3) identification of pathogenic agents important in public health; (4) surveillance of WNV and other potential flaviviruses in mosquito populations; and (5) alert to the suitability of control measures. The REVIVE has been a key point towards consolidating the establishment of surveillance and vector control at the perimeter of ports and airports according to International Health Regulations [2,17-19].

This work aims to present an overview of the REVIVE programme regarding the surveillance of mosquitoes and flaviviruses ongoing in Portugal. The displayed data was produced from mosquito collections performed between 2008 and 2013 on a bi-monthly basis in several Portuguese regions.

\section{Materials and Methods}

\subsection{Mosquito Collection}

Within the framework of arboviruses surveillance programs, the National Institute of Health has been studying the mosquito fauna of several Portuguese provinces to ascertain potential infection risks 
to the human population [20,21]. The REVIVE programme is based on a strategy of collection ranging from monthly to biweekly or even weekly adult and immature mosquito sampling, which were performed over two to three continuous nights at the same collection site, depending on the particular ability of regional entities to participate in the programme. The periodicity of mosquito sampling is defined in the beginning of every collection season and taken throughout the period, and sampling sites are not changed. The programme has been running since 2008 with field mosquito collection starting in May and ending in October each year. Adult mosquitoes were caught with Centre for Disease Control miniature light traps (CDC traps) baited with $\mathrm{CO}_{2}$ and set for a minimum of $12 \mathrm{~h}$ periods covering sunset to sunrise. Mosquitoes were inactivated by placing them in a $4{ }^{\circ} \mathrm{C}$ refrigerator or killed by freezing and identified under a stereomicroscope, on a chill table, using the identification keys of Ribeiro et al. [22] and Schaffner et al. [23]. Larvae were commonly collected using a dipper in the same localities and districts and also by occasional collection. Larvae were transported to the laboratory and identified using the same identification keys.

\subsection{Ports and Airports}

Within the framework of REVIVE, seven ports (Aveiro, Figueira da Foz, Leixões, Portimão, Setúbal, Sines, and Viana do Castelo), one dock (Vila Real de Santo António) and two international airports (Faro and Porto) have been surveyed by ovitraps and CDC light-traps according to International Health Regulations.

\subsection{Flavivirus Survey}

Non engorged females were pooled (a maximum of 50 individuals/pool) by collection date, collection site and species. Pools were grinded in liquid nitrogen and minimal essential medium supplied with $10 \% \mathrm{FBS}$, streptomycin $(0.1 \mathrm{mg} / \mathrm{mL})$ and fungizone $(1 \mathrm{mg} / \mathrm{mL})$, centrifuged $12,000 \mathrm{~g}$ for $2 \mathrm{~min}$ in and tested for flaviviruses by RT-PCR using the commercial kit SuperScript One-Step RT-PCR (Invitrogen, Carlsbad, CA, USA) after RNA extraction with PureLink RNA Mini Kit (Ambion, Carlsbad, CA, USA). Primers were targeted to a NS5 gene fragment of flaviviruses [24,25]. Amplicons obtained by Pan-flavi PCR were purified using JET quick PCR Product Purification Spin kit (Genomed, Löhne, Germany) and sequenced by ABI Prism 3130 Genetic Analyzer (Applied Biosystems, Foster City, CA, USA). The obtained sequences were used to perform basic local alignment searches (BLAST) in GenBank [26]. DNA sequence alignment was performed using Muscle [27] and all phylogenetic analysis was performed in Mega software version 6.06 [28]. Kimura two-parameter model considering the non-uniformity of evolutionary rates among sites using a discrete Gamma distribution with five rate categories and assuming a fraction of sites to be invariable $(\mathrm{K} 2+\mathrm{G}+\mathrm{I} ;+\mathrm{G}=0.9836$ and $+\mathrm{I}=0.2225)$ with the lowest Bayesian Information Criterion was chosen among 24 different nucleotide substitution models [29]. The tree with the highest log likelihood (-3077.01) is presented. The analysis involved 46 sequences and a final dataset of 145 positions (after elimination of all gaps and missing data).

In positive pools by RT-PCR, virus isolation was attempted starting from the remaining part of the homogenates using the $\mathrm{C} 6 / 36$ cell line incubated at $28^{\circ} \mathrm{C}[30]$ and the vertebrate cell line Vero E6. 


\section{Results}

From 2008-2013 a total of 24 species were recorded in the seven regions (Nomenclature of territorial units for statistics II-NUTS II), 20 subregions (NUTS III) and 151 counties under REVIVE (Figure 1). Between 2008 and 2013, the REVIVE trapped around 500,000 adult mosquitoes, from which 116,808 were identified belonging to 22 species in 3335 trap-nights (Table 1). The most common were Culex pipiens $(38,941 ; 33 \%)$, followed by $C x$. theileri $(30,845 ; 26 \%)$ and Ochlerotatus caspius $(30,559 ; 26 \%)$ (Table 2). In the immature collections, 17 species were identified in 3618 positive larvae surveys (Table 1). The three most collected species were Cx. pipiens (36,531; 49\%), Culiseta longiareolata $(29,672 ; 40 \%)$ and Aedes aegypti (2173; 3\%) (Table 2).

A total of 428 trap-nights and 930 immature collections were performed in international ports and airports, resulting in a total collection of 13,984 adult mosquitoes and 2907 immatures (Table 3). In these critical gateways for invasive mosquitoes, only autochthonous mosquitoes were identified in mainland Portugal, mostly from the species Cs. longiareolata, Cx. pipiens and Oc. caspius.

Figure 1. Geographic area under REde de VIgilância de VEctores (REVIVE); seven regions, 20 subregions and 151 counties (not to scale).

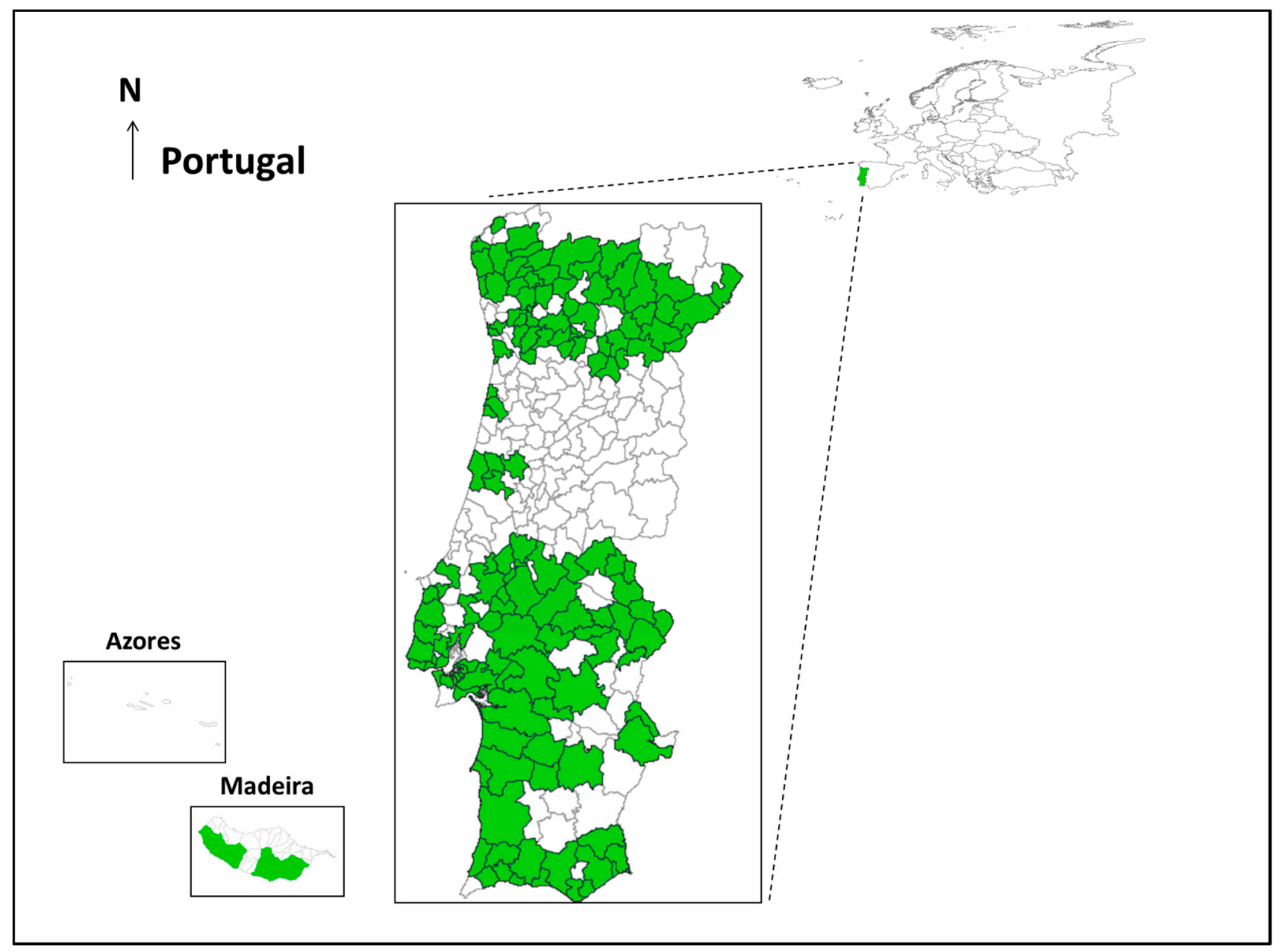


Table 1. Summary of collections in the frame of REVIVE.

\begin{tabular}{ccccccccc}
\hline Collections & Number of & $\mathbf{2 0 0 8}$ & $\mathbf{2 0 0 9}$ & $\mathbf{2 0 1 0}$ & $\mathbf{2 0 1 1}$ & $\mathbf{2 0 1 2}$ & $\mathbf{2 0 1 3}$ & Total \\
\hline \multirow{4}{*}{ Adult } & CDC Trap-night & 267 & 227 & 464 & 725 & 719 & 933 & 3335 \\
Collection & Adult mosquitoes & 18,310 & 23,336 & 25,790 & 12,739 & 21,127 & 15,506 & 116,808 \\
& Species number & 15 & 13 & 13 & 22 & 17 & 19 & 22 \\
& Sub-regions (NUTS III) & $\mathbf{1 9}$ & $\mathbf{1 1}$ & $\mathbf{1 5}$ & $\mathbf{1 9}$ & $\mathbf{2 0}$ & $\mathbf{2 0}$ & $\mathbf{2 0}$ \\
\hline \multirow{3}{*}{ Immature } & Surveyed breeding sites & 143 & 59 & 166 & 518 & 697 & 2035 & 3618 \\
Collection & Immature mosquitoes & 3338 & 2125 & 4562 & 14,526 & 25,988 & 23,850 & 74,389 \\
& Species number & 8 & 7 & 9 & 12 & 10 & 13 & 17 \\
& Sub-regions (NUTS III) & $\mathbf{1 4}$ & $\mathbf{9}$ & $\mathbf{1 3}$ & $\mathbf{1 9}$ & $\mathbf{2 0}$ & $\mathbf{2 0}$ & $\mathbf{2 0}$ \\
\hline
\end{tabular}

Table 2. Mosquito species collected in Portugal in the frame of REVIVE.

\begin{tabular}{|c|c|c|c|c|c|c|c|}
\hline Species & Larvae & $\delta^{11}$ & $q^{2}$ & $\partial \boldsymbol{\&} q^{3}$ & Pools ${ }^{4}$ & $\uparrow$ Pools $^{5}$ & $\%$ \% Pools ${ }^{6}$ \\
\hline Aedes aegypti & 2173 & 606 & 195 & 801 & 53 & 725 & 1.82 \\
\hline Ae. eatoni & 8 & & 2 & 2 & & & 0.00 \\
\hline Anopheles algeriensis & & 6 & 437 & 443 & 7 & 278 & 0.70 \\
\hline An. claviger & & 16 & 110 & 126 & 5 & 54 & 0.14 \\
\hline An. maculipennis s.l. & 295 & 124 & 645 & 769 & 44 & 404 & 1.01 \\
\hline An. plumbeus & & & 8 & 8 & & & 0.00 \\
\hline Coquillettidea richiardii & & & 75 & 75 & 6 & 55 & 0.14 \\
\hline Culiseta annulata & 140 & 3 & 237 & 240 & 10 & 62 & 0.16 \\
\hline Cs. longiareolata & 29,672 & 570 & 439 & 1009 & 15 & 52 & 0.13 \\
\hline Culex hortensis & 1578 & 4 & 13 & 17 & 2 & 5 & 0.01 \\
\hline Cx. impudicus & 120 & 3 & & 3 & & & 0.00 \\
\hline Cx. laticinctus & 1908 & 54 & 25 & 79 & & & 0.00 \\
\hline Cx. mimeticus & 3 & 3 & 8 & 11 & 1 & 6 & 0.02 \\
\hline Cx. modestus & 1 & 1 & 225 & 226 & 6 & 168 & 0.42 \\
\hline Cx. perexiguus & 67 & 144 & 1303 & 1447 & 79 & 929 & 2.33 \\
\hline Cx. pipiens & 36,531 & 4727 & 34,214 & 38,941 & 696 & 19,181 & 48.11 \\
\hline Cx. territans & 50 & & & & & & 0.00 \\
\hline Cx. theileri & 1300 & 648 & 30,197 & 30,845 & 241 & 8037 & 20.16 \\
\hline Cx. torrentium & 359 & & & & & & 0.00 \\
\hline Ochlerotatus berlandi & & & 9 & 9 & 2 & 17 & 0.04 \\
\hline Oc. caspius & 12 & 1038 & 29,521 & 30,559 & 209 & 8456 & 21.21 \\
\hline Oc. detritus & 172 & 409 & 10,553 & 10,962 & 40 & 1409 & 3.53 \\
\hline Oc. geniculatus & & & 55 & 55 & 2 & 21 & 0.05 \\
\hline Uranotaenia unguiculata & & 114 & 67 & 181 & 1 & 13 & 0.03 \\
\hline Total & 74,389 & 8470 & 108,338 & 116,808 & 1419 & 39,872 & 100.00 \\
\hline
\end{tabular}

Notes: ${ }^{1}$ Number of identified adult male mosquitoes; ${ }^{2}$ Number of identified adult female mosquitoes;

3 Total number of identified adult mosquitoes; ${ }^{4}$ Number of mosquito pools screened for flaviviruses;

${ }^{5}$ Number of female mosquitoes screened for flaviviruses in pools; ${ }^{6}$ Percentage of female mosquitoes screened for flaviviruses in pools. 
Table 3. Mosquito species identified in the frame of REVIVE in international maritime ports and airports.

\begin{tabular}{|c|c|c|c|c|c|c|c|c|c|c|c|c|c|c|c|c|c|c|}
\hline \multirow[t]{2}{*}{$\begin{array}{l}\text { Points of } \\
\text { Entry }\end{array}$} & \multicolumn{2}{|c|}{ Collections } & \multicolumn{2}{|c|}{$\mathbf{N}$} & \multirow{2}{*}{$\begin{array}{c}\begin{array}{c}\text { Ae. } \\
\text { aegypti }\end{array} \\
\text { IM } \\
\end{array}$} & \multicolumn{2}{|c|}{$\begin{array}{c}\text { An. } \\
\text { maculipennis }\end{array}$} & \multirow{2}{*}{$\begin{array}{c}\begin{array}{c}C x \\
\text { hortensis }\end{array} \\
\text { IM } \\
\end{array}$} & \multicolumn{2}{|c|}{$\begin{array}{c}C x . \\
\text { pipiens }\end{array}$} & \multicolumn{2}{|c|}{$\begin{array}{c}\text { Cs. } \\
\text { annulata }\end{array}$} & \multicolumn{2}{|c|}{$\begin{array}{c}\text { Cs. } \\
\text { longiareolata }\end{array}$} & \multirow{2}{*}{$\begin{array}{c}\begin{array}{c}C x . \\
\text { theileri }\end{array} \\
\mathrm{AD} \\
\end{array}$} & \multirow{2}{*}{$\begin{array}{c}\begin{array}{c}\text { Oc. } \\
\text { caspius }\end{array} \\
\mathrm{AD}\end{array}$} & \multicolumn{2}{|c|}{$\begin{array}{c}\text { Oc. } \\
\text { detritus }\end{array}$} \\
\hline & $\mathrm{IM}^{1}$ & $\mathrm{AD}^{2}$ & IM & $\mathrm{AD}$ & & $\mathrm{IM}$ & $\mathrm{AD}$ & & IM & $\mathrm{AD}$ & $\mathrm{IM}$ & $\mathrm{AD}$ & IM & $\mathrm{AD}$ & & & IM & $\mathrm{AD}$ \\
\hline Aveiro & 13 & 62 & 55 & 96 & & & 1 & & & 37 & & & 55 & 14 & & 43 & & 1 \\
\hline Faro-Airport & 400 & 55 & 725 & 1934 & & & 4 & & 12 & 599 & & & 338 & 6 & 139 & 1025 & & 139 \\
\hline Figueira da Foz & 6 & 63 & 240 & 10,206 & & & 3 & & 240 & 863 & & & & 9 & 230 & 9029 & & 72 \\
\hline $\begin{array}{l}\text { Funchal } \\
\text { (Madeira Island) }\end{array}$ & 1 & & 20 & & 20 & & & & & & & & & & & & & \\
\hline $\begin{array}{l}\text { Machico } \\
\text { (Madeira Island) }\end{array}$ & 1 & & 7 & & & & & & & & & & 7 & & & & & \\
\hline Porto-Airport & 1 & 41 & & 7 & & & & & & 7 & & & & & & & & \\
\hline Matosinhos & 8 & 123 & 111 & 1378 & & & & & 10 & 1371 & & 1 & 101 & 4 & 2 & & & \\
\hline Portimão & 55 & 52 & 141 & 308 & & & & & 100 & 196 & & & 41 & 63 & 7 & 40 & & \\
\hline Setúbal & 228 & 6 & & 1 & & & & & & 1 & & & & & & & & \\
\hline Sines & 23 & 15 & 423 & 32 & & 1 & & & 23 & 16 & & 3 & 395 & 4 & 4 & 5 & 4 & \\
\hline $\begin{array}{l}\text { Viana do } \\
\text { Castelo }\end{array}$ & 46 & 11 & 702 & 22 & & & & 44 & 293 & 1 & 74 & & 291 & 1 & & 20 & & \\
\hline $\begin{array}{l}\text { Vila Real de } \\
\text { Santo António }\end{array}$ & 148 & & 483 & & & & & & 201 & & & & 282 & & & & & \\
\hline Total & 930 & 428 & 2907 & 13,984 & 20 & 1 & & 44 & 879 & 3091 & 74 & 4 & 1510 & 101 & 382 & 10,162 & 4 & 212 \\
\hline
\end{tabular}


In Madeira, the main concern was the surveillance of the invasive species Ae. aegypti. A total of 227 immature collections and 482 trap nights were performed in Madeira since the beginning of 2010, resulting in a collection of 5256 immatures and 1471 adult mosquitoes (Table 4). The most abundant species were Ae. aegypti found in five counties of Madeira.

A total of 39,872 female adult mosquitoes were pooled and screened for flaviviruses surveillance (Tables 2 and 5). An average of 237 pools and 6645 mosquitoes were processed every year. All pools were negative for the presence of WNV RNA. Insect-Specific Flaviviruses (ISFs) have been detected in Aedes, Culex and Ochlerotatus mosquitoes. This group of flaviviruses presents a high genetic diversity and, so far, it has only been detected or isolated in mosquitoes, being unable to replicate in vertebrate cells. Within REVIVE three different ISFs have been detected in 36 pools (2.5\%): (1) in Ae. aegypti from Madeira Island in 2010 (two detections) and 2013 (Genbank representative sequences: HQ676624 and HQ676625); (2) in Cx. theileri in Central and Southern regions of Portugal in 2008, 2009 and 2010 and in Madeira Island in 2010 (Culex FV Genbank representative sequences: HQ676619 to HQ676623); and (3) in Oc. caspius in 2008 in Algarve (Genbank representative sequence: HQ676618; Table 5 and Figure 2).

Table 4. Mosquito species identified in the frame of REVIVE in Madeira Island.

\begin{tabular}{|c|c|c|c|c|c|c|c|c|c|c|c|c|c|}
\hline \multirow[t]{2}{*}{ Counties } & \multicolumn{2}{|c|}{ Collections } & \multicolumn{2}{|c|}{$\mathbf{N}$} & \multicolumn{2}{|c|}{$\begin{array}{c}\text { Ae. } \\
\text { aegypti }\end{array}$} & \multirow{2}{*}{$\begin{array}{c}\begin{array}{c}\text { Ae. } \\
\text { eatoni }\end{array} \\
\text { AD }\end{array}$} & \multicolumn{2}{|c|}{$\begin{array}{c}\text { Cs. } \\
\text { longiareolata }\end{array}$} & \multicolumn{2}{|c|}{$\begin{array}{c}C x . \\
\text { pipiens }\end{array}$} & \multicolumn{2}{|c|}{$\begin{array}{c}\text { Cx. } \\
\text { theileri }\end{array}$} \\
\hline & IM & AD & IM & AD & IM & AD & & IM & AD & IM & AD & IM & AD \\
\hline Calheta & 20 & 1 & 141 & 23 & 136 & 23 & & & & 5 & & 20 & \\
\hline Câmara de Lobos & 33 & 123 & 805 & 464 & 715 & 338 & 1 & 82 & 31 & 8 & 88 & 33 & 6 \\
\hline Funchal & 161 & 358 & 4154 & 984 & 1295 & 440 & 1 & 261 & 159 & 1967 & 270 & 161 & 114 \\
\hline Machico & 4 & & 57 & & & & & 57 & & & & 4 & \\
\hline Ponta do Sol & 1 & & 14 & & 12 & & & & & 2 & & 1 & \\
\hline Ribeira Brava & 2 & & 8 & & & & & & & & & 2 & \\
\hline Santa Cruz & 6 & & 77 & & 15 & & & 51 & & 11 & & 6 & \\
\hline Total & 227 & 482 & 5256 & 1471 & 2173 & 801 & 2 & 451 & 190 & 1993 & 358 & 227 & 120 \\
\hline
\end{tabular}

Table 5. Flaviviruses detected in mosquitoes collected in Portugal in the frame of REVIVE.

\begin{tabular}{lccccccc}
\hline Number of & $\mathbf{2 0 0 8}$ & $\mathbf{2 0 0 9}$ & $\mathbf{2 0 1 0}$ & $\mathbf{2 0 1 1}$ & $\mathbf{2 0 1 2}$ & $\mathbf{2 0 1 3}$ & Total \\
\hline Pools & 214 & 164 & 230 & 328 & 251 & 232 & $\mathbf{1 4 1 9}$ \\
Pools & 6785 & 5230 & 5093 & 7425 & 7947 & 7392 & $\mathbf{3 9 , 8 7 2}$ \\
Culex FV & 5 & 0 & 3 & 7 & 0 & 0 & $\mathbf{1 5}$ \\
Ochlerotatus FV & 1 & 1 & 1 & 4 & 0 & 0 & 7 \\
Ae. aegypti FV & 0 & 0 & 3 & 7 & 0 & 4 & $\mathbf{1 4}$ \\
\hline
\end{tabular}

Notes: Genebank sequences representative of ISFs: HQ676619 to HQ676623 (Culex FV); HQ676618 (Ochlerotatus FV); HQ676624 and HQ676625 (Ae. aegypti FV). 
Figure 2. Maximum-likelihood tree obtained from NS5 partial sequences using Kimura two-parameter model of ISFs sequences detected under REVIVE and GenBank sequences of other flaviviruses. Bootstrap values (1000 replicates) above $60 \%$ are shown.

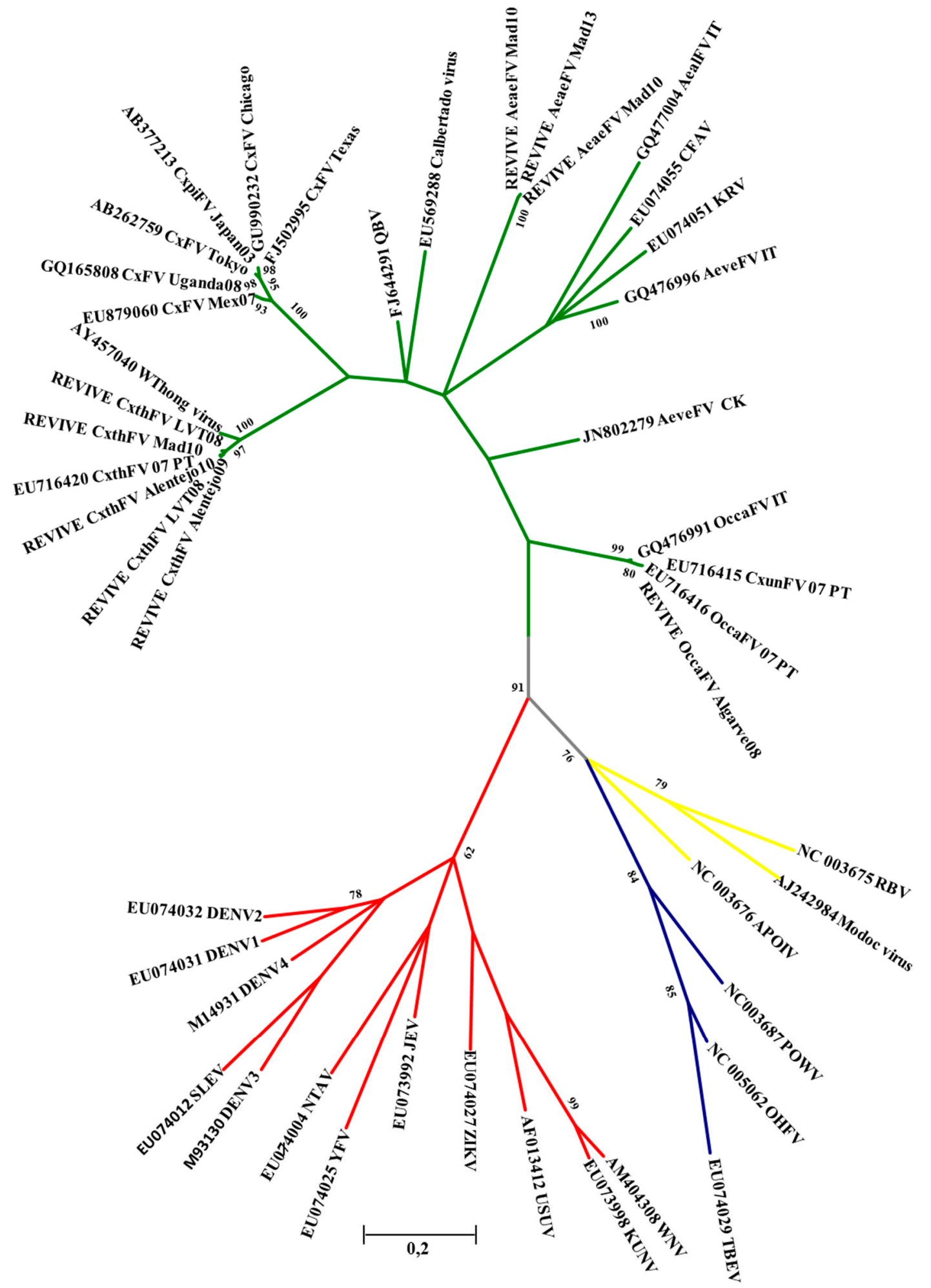

Notes: Bar, number of substitutions per site. Branches: green Insect Specific Flavivirus (ISFs); yellow, no-known vector; blue, tick-borne flaviviruses and red, pathogenic mosquito-borne flaviviruses; CK, Czech Republic; IT, Italy; PT, Portugal; LVT, Lisbon and Tagus river region; Mad, Madeira Island. 


\section{Discussion}

Mosquito-borne diseases are (re-) emerging threats to Europe where globalization and environmental changes, together with other interacting drivers such as social and demographic change and health system policy, pose obvious challenges when it comes to vector-borne diseases [18]. Rather than relying on an emergency response, REVIVE allows timely detection of changes in abundance and species diversity providing valuable knowledge to health authorities, the scientific community and entities which may take control measures of vector populations reducing their impact on public health.

Since its inception in 2008, REVIVE has been responsible for the establishment and implementation of guidelines for the surveillance of arthropod vectors of disease with impact on public health. These guidelines were set according to the European Centre for Disease Prevention and Control (ECDC) guidelines for the surveillance of invasive mosquitoes in Europe, in order to be in line at a European level with other countries/areas under surveillance [10]. Methods and information records for the surveillance of invasive mosquitoes in Europe are being followed and since 2010 the REVIVE collaborates with the European Network for Arthropod Vector Surveillance for Human Public Health (VBORNET). In 2014 the REVIVE was ongoing in all points of entry under international regulation (PoE) in Portugal. The primary vector for dengue Aedes aegypti is now found in Madeira Island, Portugal, where in 2012 was responsible for the first dengue outbreak within European territory since the 1926-1928 outbreak in Greece [7]. More than 2000 cases and 78 exportation cases into 13 other European countries via travelers departing Madeira were reported [31]. Taking this occurrence as an example, updated information on mosquito species and their geographic distribution is essential more than ever to reduce the impact of vector-borne diseases by providing an opportunity to initiate preventive actions and control methods, such as vector control, prior to the emergence of diseases in human population. According to Ribeiro and Ramos [22], the Portuguese mosquito fauna includes 45 species and subspecies distributed in 15 genera and seven subgenera. Some of the species listed in this publication have a limited distribution, are sporadic or considered only for their potential presence. The data obtained in REVIVE programme about potential vector species composition is in agreement with the work published by Ribeiro with some updates regarding geographical distribution of some species.

One useful output of REVIVE is the generation of abundance and population data on indigenous mosquito species in order to assess the ability of WNV to establish at a regional level. In Portugal, WNV was demonstrated to be circulating in epizootic transmission since 1966/1967 and was first isolated in 1969 from Anopheles maculipennis [32,33]. No clinical cases were reported until the summer of 2004 when two tourists acquired WNV in the Southern province of Algarve [34], after which the WNV was isolated from mosquitos sampled from the same region [35]. Every year WNV circulation is detected in birds in Portugal [36]. In 2010 a probable human case of WNV was identified in southern Portugal supporting yearly enzootic circulation of the virus and the risk for human transmission [37].

Insect specific flaviviruses (ISFs) have been increasingly reported from all over the world, and are considered a fourth group within the Flavivirus genus unable to replicate in vertebrate cells [38]. Traditionally, flaviviruses are divided into three groups: viruses transmitted by mosquitoes, viruses transmitted by ticks, and viruses with no known vector. The increased number of known ISFs 
agree with previous studies suggesting a larger number of unsampled taxa in Flavivirus genus [39], namely species distantly related to classical arthropod-borne flaviviruses [40,41]. Some studies even indicate that the Flaviviridae family or otherwise, the genus Flavivirus, may suffer some reorganization in the near future, in a way to better assign this "incoming" species diversity [42]. Furthermore, the presence of DNA sequences similar to ISFs in mosquito genomes from the genera Aedes and Ochlerotatus also suggests a close evolution between these viruses and their mosquito hosts [43-46].

The importance of these viruses in nature has not been yet elucidated; however, it is thought that in situations of co-infection they may prevent the transmission of pathogenic virus. Although there are studies supporting this hypothesis [46,47], there are also evidences for positive interactions between WNV and ISFs [48,49].

Preliminary studies in Marim virus, an ISF isolated from a Oc. caspius mosquito pool (collected in Algarve in 2007), indicate that in co-infection or superinfection scenarios the replication of WNV seems to be reduced (unpublished data). Marim ISF groups with Ochlerotatus FV (Table 5 and Figure 2), and unlike most described ISFs, was detected in different mosquito genera and species (Cx. univitattus, Cx. theileri, Cx. pipiens, Oc. detritus, Oc. caspius) in Portugal and Greece (Oc. caspius). Considering this WNV suppression hypothesis, the presence of naturally infected mosquito populations with ISFs could decrease the risk of human infection in Portugal. However further studies are needed to clarify the interactions of Marim virus on WNV infection, dissemination and transmission.

\section{Conclusions}

The REVIVE represents a successful layout for mosquito surveillance at national level, in which entomologists, virologists, public health professionals, and policy makers have a high degree of cooperation aiming for an effective surveillance program. With seven years of experience, additional challenges include: to increase the surveyed area, mostly in the Central region of the country and also including Azores Islands; to set collection sites in points of entry from Spain, thus increasing the ability for early detection of Ae. albopictus; and the cooperation and closer integration with surveillance across national borders at a European level, contributing to a Europe-wide surveillance network. This would greatly assist in data comparison and sharing among European regions.

\section{Acknowledgments}

We are grateful to the Portuguese National Program for Vector Surveillance (REVIVE) workgroup for mosquito collection. This work was partially supported by the Fundação para a Ciência e Tecnologia (FCT) under the project "New arboviruses isolated in Portugal. Risk assessment and public health application" (PTDC/SAU-SAP/119199/2010).

\section{Author Contributions}

Hugo Osório is responsible for identifying and processing mosquitoes within the Portuguese National Program for Vector Surveillance (REVIVE). Líbia Zé-Zé performed the molecular analyses for flaviviruses identification. Fátima Amaro was responsible for nucleic acid extractions. Maria J. Alves is 
the coordinator for the Portuguese National Program for Vector Surveillance (REVIVE). All authors wrote, reviewed the manuscript and approved the final version.

\section{Conflicts of Interest}

The authors declare no conflict of interest.

\section{References}

1. Petric, D.; Bellini, R.; Scholte, E.-J.; Rakotoarivony, L.M.; Schaffner, F. Monitoring population and environmental parameters of invasive mosquito species in Europe. Parasit. Vectors 2014, 7 , doi:10.1186/1756-3305-7-187.

2. Guidelines for the Surveillance of Invasive Mosquitoes in Europe; European Centre for Disease Prevention and Control: Stockholm, Sweden, 2012.

3. Angelini, R.; Finarelli, A.C.; Angelini, P.; Po, C.; Petropulacos, K.; Silvi, G.; Macini, P.; Fortuna, C.; Venturi, G.; Magurano, F.; et al. Chikungunya in north-eastern Italy: A summing up of the outbreak. Euro Surveill. 2007, 12. Available online: http://www.eurosurveillance.org/ ViewArticle.aspx?ArticleId=3313 (accessed on 4 November 2014).

4. Grandadam, M.; Caro, V.; Plumet, S.; Thiberge, J.M.; Souares, Y.; Failloux, A.B.; Tolou, H.J.; Budelot, M.; Cosserat, D.; Leparc-Goffart, I.; et al. Chikungunya virus, southeaster France. Emerg. Infect. Dis. 2011, 17, 910-913.

5. La Ruche, G.; Souares, Y.; Armengaud, A.; Peloux-Petiot, F.; Delaunay, P.; Despres, P.; Lenglet, A.; Jourdain, F.; Leparc-Goffart, I.; Charlet, F.; et al. First two autochthonous dengue virus infections in metropolitan France, September 2010. Eur. Surveill. 2010, 15. Available online: http://www.eurosurveillance.org/ViewArticle.aspx?ArticleId=19676 (accessed on 4 November 2014).

6. Gjenero-Margan, I.; Aleraj, B.; Krajcar, D.; Lesnikar, V.; Klobučar, A.; Pem-Novosel, I.; Kurečić-Filipović, S.; Komparak, S.; Martić, R.; Duričić, S.; et al. Autochthonous dengue fever in Croatia, August-September 2010. Eur. Surveill. 2011, 16. Availaboe online: http://www.eurosurveillance.org/ViewArticle.aspx?ArticleId=19805 (accessed on 4 November 2014).

7. Alves Alves, M.J.; Fernandes, P.L.; Amaro, F.; Osório, H.; Luz, T.; Parreira, P.; Andrade, G.; Zé-Zé, L.; Zeller, H. Clinical presentation and laboratory findings for the first autochthonous cases of dengue fever in Madeira island, Portugal, October 2012. Eur. Surveill. 2013, 18. Available online: http://www.eurosurveillance.org/ViewArticle.aspx?ArticleId=20398 (accessed on 4 November 2014).

8. Autochonous Dengue Cases in Madeira, Portugal; European Centre for Disease Prevention and Control: Stockholm, Sweden, 2012.

9. Schäfer, M.; Lundström, J.; Pfeffer, M.; Lundkvist, E.; Landin, J. Biological diversity vs. risk for mosquito nuisance and disease transmission in constructed wetlands in southern Sweden. Med. Vet. Entomol. 2004, 18, 256-268.

10. Schaffner, F.; Bellini, R.; Petrić, D.; Scholte, E.-J.; Zeller, H.; Rakotoarivony, L.M. Development of guidelines for the surveillance of invasive mosquitoes in Europe. Parasit. Vectors 2013, 6, doi:10.1186/1756-3305-6-209. 
11. Pervanidou, D.; Detsis, M.; Danis, K.; Mellou, K.; Papanikolaou, E.; Terzaki, I.; Baka, A.; Veneti, L.; Vakali, A.; Dougas, G.; et al. West Nile virus outbreak in humans, Greece, 2012: Third consecutive year of local transmission. Eur. Surveill. 2014, 19. Available online: http://www.eurosurveillance.org/ViewArticle.aspx?ArticleId=20758 (accessed on 4 November 2014).

12. Rosà, R.; Marini, G.; Bolzoni, L.; Neteler, M.; Metz, M.; Deluchi, L.; Chadwick, E.; Balbo, L.; Mosca, A.; Giacobini, M.; et al. Early warning of West Nile virus mosquito vector: Climate and land use models successfully explain phenology and abundance of Culex pipiens mosquitoes in north-western Italy. Parasit. Vectors 2014, 7, doi:10.1186/1756-3305-7-269.

13. Arends, J.E.; Oosterheert, J.J.; Kraaij-Dirkswager, M.M.; Kaan, J.A.; Fanoby, E.B.; Haas, P.J.; Scholte, E.J.; Kortbeek, L.M.; Sankatsing, S.U. Two cases of Plasmodium falciparum malaria in the Netherlands without recent travel to a malaria-endemic country. Amer. J. Trop. Med. Hyg. 2013, 13, doi:10.4269/ajtmh.13-0213.

14. Doudier, B.; Bogreau, H.; DeVries, A.; Ponçon, N.; Stauffer, W.M.; Fontenille, D.; Rogier, C.; Parola, P. Possible autochthonous malaria from Marseille to Minneapolis. Emerg. Infect. Dis. 2007, 13, 1236-1238.

15. Ioannidis, A.; Nicolaou, C.; Stoupi, A.; Kossyvakis, A.; Matsoukas, P.; Liakata, M.V.; Magiorkinis, E.; Petinaki, E.; Chatzpanagiotou, S. First report of a phylogenetic analysis of an autochthonous Plasmodium vivax strain isolated from a malaria case in east Attica, Greece. Malar. J. 2013, 12, doi:10.1186/1475-2875-12-299.

16. Santa-Olalla, P.; Vazquez-Torres, M.C.; Latorre-Fandos, E.; Mairal-Claver, P.; Cortina-Solano, P.; Puy-Azón, A.; Sancho, A.B.; Leitmeyer, K.; Lucientes-Curdi, J.; Sierra-Moros, M.J. First autochthonous malaria case due to Plasmodium vivax since eradication, Spain, October 2010. Eur. Surveill. 2010, 15. Available online: http://www.eurosurveillance.org/ViewArticle.aspx? ArticleId=19684 (accessed on 4 November 2014).

17. Diário da República Eletrónico. International Health Regulations, 2005. Available online: http://www.dre.pt/pdf1sdip/2008/01/01600/0063800687.PDF (accessed on 20 August 2014).

18. Semenza, J.C.; Zeller, H. Integrated surveillance for prevention and control of emerging vector-borne diseases in Europe. Euro Surveill. 2014, 19. Avilable online: http://www.eurosurveillance.org/images/ dynamic/EE/V19N13/art20757.pdf (accessed on 4 November 2014).

19. Word Health Organization. Alert, Response, and Capacity Building under the International Health Regulations (IHR). Available online: http://www.who.int/ihr/ports_airports/ihr_authorized_ ports_list.pdf?ua=1 (accessed on 20 August 2014).

20. Alves, M.J.; Osório, H.C.; Zé-Zé, L.; Amaro, F. Relatório REVIVE 2008/2009—Programa Nacional de Vigilância de Vectores Culicídeos; Instituto Nacional de Saúde Dr. Ricardo Jorge: Lisboa, Portugal, 2010 (in Portuguese).

21. Alves, M.J.; Osório, H.C.; Amaro, F.; Zé-Zé, L. Relatório REVIVE 2013-Programa Nacional de Vigilância de Vectores Culicídeos; Instituto Nacional de Saúde Dr. Ricardo Jorge: Lisboa, Portugal, 2013 (in Portuguese).

22. Ribeiro, H.; Ramos, H.C. Identification keys of the mosquitoes of continental Portugal, Açores and Madeira. Eur. Mosq. Bull. 1999, 3, 1-11. 
23. Schaffner, E.; Anges, G.; Geoffroy, B.; Hervy, J.-P.; Rhaiem, A.; Brunhes, J. The Mosquitoes of Europe: An Identification and Training Programme; IRD Editions: Montpellier, France, 2001.

24. Brise, T.; Jia, X.Y.; Huang, C.; Grady, L.J.; Lipkin, W.I. Identification of a Kunjin/West Nile-like flavivirus in brains of patients with New York encephalitis. Lancet 1999, 354, 1261-1262.

25. Briese, T.; Rambaut, A.; Pathmajeyan, M.; Bishara, J.; Weinberg, M.; Pitlik, S.; Lipkin, W.I. Phylogenetic analysis of a human isolate from the 2000 Israel West Nile virus epidemic. Emerg. Infect. Dis. 2002, 8, 528-531.

26. Altschul, S.F.; Madden, T.L.; Schäffner, A.A.; Zhang, J.; Zhang, Z.; Miller, W.; Lipman, D.J. Gapped BLAST and PSI-BLAST: A new generation of protein database search programs. Nucleic Acids Res. 1997, 25, 3389-3402.

27. Edgar, R.C. MUSCLE: Multiple sequence alignment with high accuracy and high throughput. Nucleic Acids Res. 2004, 32, 1792-1797.

28. Tamura, K.; Stecher, G.; Peterson, D.; Filipski, A.; Kumar, S. MEGA6: Molecular Evolutionary Genetics Analysis version 6.0. Mol. Biol. Evol. 2013, 30, 2725-2729.

29. Nei, M.; Kumar, S. Molecular Evolution and Phylogenetics; Oxford University Press: New York, NY, USA, 2000.

30. Igarashi, A.; Harrap, K.A.; Casals, J.; Stollar, V. Morphological, biochemical, and serological studies on a viral agent. Virology 1976, 74, 174-187.

31. Wilder-Smith, A.; Quam, M.; Sessions, O.; Rocklov, J.; Liu-Helmersson, J.; Franco, L.; Khan, K. The 2012 dengue outbreak in Madeira: Exploring the origins. Eur. Surveill. 2014, 19. Available online: http://www.eurosurveillance.org/ViewArticle.aspx?ArticleId=20718 (accessed on 4 November 2014).

32. Filipe, A.R.; Pinto, M.R. Isolation in Portugal of West Nile virus from Anopheles. Acta Virol. 1972, 16, 361.

33. Filipe, A.R.; Pinto, M.R. Survey for antibodies to arboviruses in serum of animals from southern Portugal. Amer. J. Trop. Med. Hyg. 1969, 18, 423-426.

34. Connell, J.; McKeown, P.; Garvey, P.; Cotter, S.; Conway, A.; O’Flanagan, D.; O’Herlihy, B.P.; Morgan, D.; Nicoll, A.; Lloyd, G. Two linked cases of West Nile virus (WNV) acquired by Irish tourists in the Algarve, Portugal. Eur. Surveill. 2004, 8. Available online: http://www.eurosurveillance.org/ViewArticle.aspx?ArticleId=2517 (accessed on 4 November 2014).

35. Parreira, R.; Severino, P.; Freitas, F.; Piedade, J.; Almeida, A.P.; Esteves, A. Two distinct introductions of the West Nile virus in Portugal disclosed by phylogenetic analysis of genomic sequences. Vector Borne Zoonotic Dis. 2007, 7, 344-352.

36. Barros, S.C.; Ramos, F.; Fagulha, T.; Duarte, M.; Henriques, M.; Luís, T.; Fevereiro, M. Serological evidence of West Nile virus circulation in Portugal. Vet. Microbiol. 2011, 152, 407-410.

37. Alves, M.J.; Poças, J.M.; Luz, T.; Amaro, F.; Zé-Zé, L.; Osório, H.C. West Nile virus infection in Portugal: Considerations about a clinical case with febrile syndrome and rash. Rev. Port. Doenças Infec. 2012, 8, 46-51.

38. Calzolari, M.; Zé-Zé, L.; Růžek, D.; Vázquez, A.; Jeffries, C.; Defilippo, F.; Osório, H.C.; Kilian, P.; Ruíz, S.; Fook, A.R.; et al. Detection of mosquito-only flaviviruses in Europe. J. Gen. Virol. 2012, 93, 1215-1225. 
39. Phybus, O.G.; Rambaut, A.; Holmes, E.C.; Harvey, P.H. New inferences from tree shape: Numbers of missing taxa and population growth rates. Syst. Biol. 2002, 51, 881-888.

40. Cook, S.; Bennett, S.N.; Holmes, E.C.; de Chesse, R.; Moureau, G.; de Lamballerie, X. Isolation of a new strain of the flavivirus cell fusing agent virus in a natural mosquito population from Puerto Rico. J. Gen. Virol. 2006, 87, 735-748.

41. Moureau, G.; Temmam, S.; Gonzalez, J.P.; Charrel, R.N.; Grard, G.; de Lamballerie, X. Real-time RT-PCR method for the universal detection and identification of flaviviruses. Vector Borne Zoonotic Dis. 2007, 7, 467-477.

42. De Lamballerie, X.; Crochu, S.; Billoir, F.; Neyts, J.; de Micco, P.; Holmes, E.C.; Gould, E.A. Genome sequence analysis of Tamana bat virus and its relationship with the genus Flavivirus. J. Gen. Virol. 2002, 83, 2443-2454.

43. Bolling, B.G.; Olea-Popelka, F.J.; Eisen, L.; Moore, C.G.; Blair, C.D. Transmission dynamics of an insect-specific flavivirus in a naturally infected Culex pipiens laboratory colony and effects of co-infection on vector competence for West Nile virus. Virology 2012, 427, 90-97.

44. Crochu, S.; Cook, S.; Attoui, H.; Charrel, R.N.; de Chesse, R.; Belhouchet, M.; Lemasson, J.-J.; Micco, P.; Lamballerie, X. Sequences of flavivurus-related RNA viruses persist in DNA form integrated in the genome of Aedes spp. mosquitoes. J. Gen. Virol. 2004, 85, 1971-1980.

45. Cook, S.; Moureau, G.; Kitchen, A.; Gould, E.A.; Lamballerie, X.; Holmes, E.C.; Harbach, R.E. Molecular evolution of the insect-specific flaviviruses. J. Gen. Virol. 2012, 93, 223-234.

46. Rizzo, F.; Cerutti, F.; Ballardini, M.; Mosca, A.; Vitale, N.; Radaelli, M.C.; Desiato, R.; Prearo, M.; Pautasso, A.; Casalone, C.; et al. Molecular characterization of flaviviruses from field-collected mosquitoes in northwestern Italy, 2011-2012. Parasit. Vectors 2014, 7, doi:10.1186/1756-3305-7-395.

47. Hobson-Peters, J.; Yam, A.W.; Lu, J.W.; Setoh, Y.X.; May, F.J.; Kurucz, N.; Walsh, S.; Prow, N.A.; Davis, S.S.; Weir, R.; et al. A new insect-specific flavivirus from northern Australia suppresses replication of West Nile virus and Murray Valley encephalitis virus in co-infected mosquito cells. PLoS One 2013, 8, doi:10.1371/journal.pone.0056534.

48. Kent, R.J.; Crabtree, M.B.; Miller, B.R. Transmission of West Nile virus by Culex quinquefasciatus say infected with Culex Flavivirus Izabal. PLoS Negl. Trop. Dis. 2010, 4, doi:10.1371/journal.pntd.0000671.

49. Newman, C.M.; Cerutti, F.; Anderson, T.K.; Hamer, G.L.; Walker, E.D.; Kitron, U.D.; Ruiz, M.O.; Brawn, J.D.; Goldberg, T.L. Culex flavivirus and West Nile virus mosquito coinfection and positive ecological association in Chicago, United States. Vector Borne Zoonotic Dis. 2011, 11, $1099-1105$.

(C) 2014 by the authors; licensee MDPI, Basel, Switzerland. This article is an open access article distributed under the terms and conditions of the Creative Commons Attribution license (http://creativecommons.org/licenses/by/4.0/). 